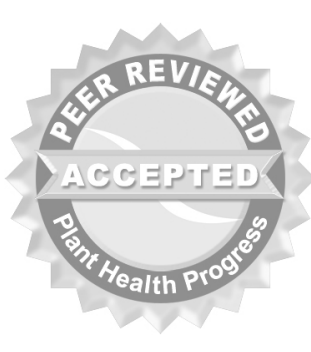

(c) 2010 Plant Management Network.

Accepted for publication 18 August 2010. Published 15 September 2010.

\title{
First Report of Pseudoperonospora rumicis Causing Downy Mildew on Rumex vesicarius in India
}

\author{
Satish K. Sain and M. L. Chadha, AVRDC-The World Vegetable \\ Center, Regional Center for South Asia (RCSA), International Crop \\ Research Institute for Semi-Arid Tropics (ICRISAT) campus, \\ Patancheru, Andhra Pradesh, 502324 India
}

Corresponding author: Satish K. Sain. sain.skumar@gmail.com

Sain, S. K., and Chadha, M. L. 2010. First Report of Pseudoperonospora rumicis causing downy mildew on Rumex vesicarius in India. Online. Plant Health Progress doi: 10.1094/PHP-2010-0915-01-BR.

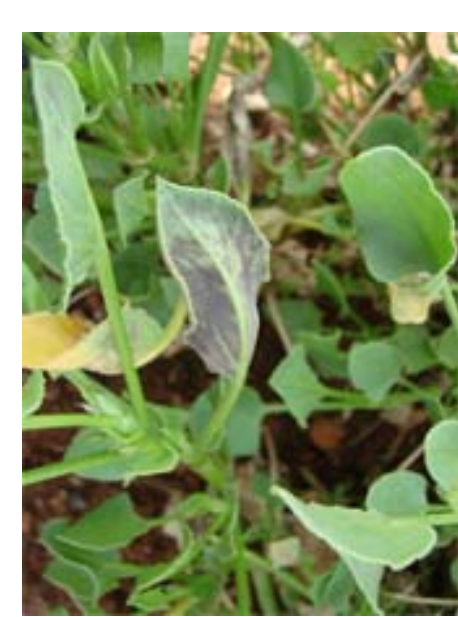

Fig. 1. Downy mildew symptoms and signs on infected leaves of Rumex vesicarius.
Bladder dock (Rumex vesicarius L., family Polygonaceae) is an important biennial bushy vegetable in southern India. The young leaves have a piquant flavor and sour taste, and are eaten boiled or raw in salads. The dried roots are ground into powder and used to treat diarrhoea and bleeding. From September to November 2007 and 2008 symptoms and signs consistent with downy mildew were observed on $\mathrm{R}$. vesicarius at the AVRDC-RCSA field plots in Hyderabad, India (Fig. 1). Initial symptoms included chlorotic lesions on the leaf blade, curling of the affected leaf tissues, and later in the season blighting of the entire plant foliage. During wet weather or high relative humidity, sporangiophores with sporangia were abundantly produced on the abaxial and occasionally on the adaxial sides of the middle and lower leaves (Fig. 2) resulting in a purple-gray appearance. Sporangiophores, 313-573 $\mu \mathrm{m}$ long, emerged in groups of 3 to 15 through stomata. They were dichotomously branched, tree-like, straight to sub-straight, slightly swollen at the base and ended with sterigmata at acute angles (with the tips of the branches acute) bearing single sporangium. Sporangia were thin-walled papillate, poroid, operculate, ellipsoidal, hyaline to olivaceous brown in color, with a mean length of $46.7 \mu \mathrm{m}(32.9-60.5 \mu \mathrm{m})$ and a mean width of $30.4 \mu \mathrm{m}(17.9-42.9 \mu \mathrm{m})$ (Fig. 3). The sporangia germinated indirectly by producing 40 to 60 globose zoospores (diameter 9-15 $\mu \mathrm{m}$ ) per sporangium. 


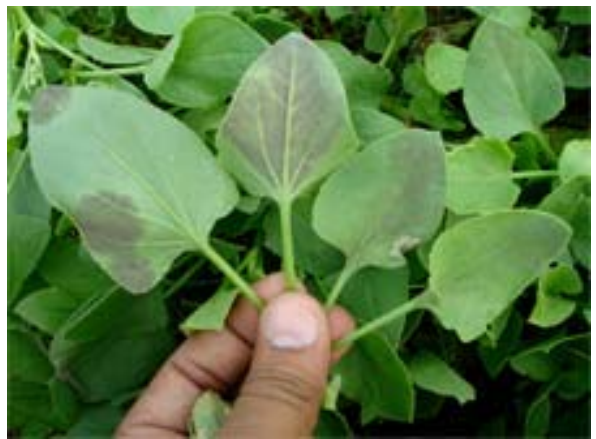

Fig. 2. Downy mildew growth on both abaxial and adaxial sides of infected Rumex vesicarius leaves.

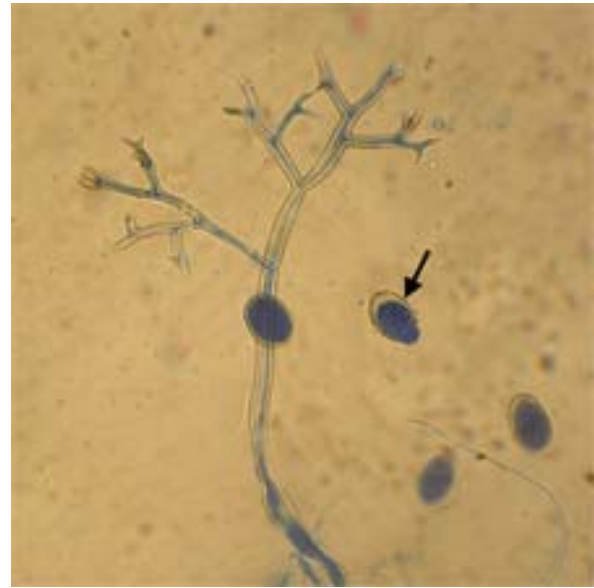

Fig. 3. Sporangiophore, sporangia and germinating sporangium (arrow) of Pseudoperonospora rumicis collected from infected leaves of Rumex vesicarius.

Pathogenicity was confirmed by inoculating leaves of 45-day-old healthy $\mathrm{R}$. vesicarius plants grown in 14-cm-diameter pots with a freshly developed zoospore and sporangial suspension $\left(1 \times 10^{5}\right.$ sporangia/ $\left.\mathrm{ml}\right)$ prepared from sporulating leaves ( 5 to 6 days after infection/lesion development) by gently brushing the sporangia into double-distilled water with an artist's brush. The sporangia were incubated at $20^{\circ} \mathrm{C}$ to allow for zoospore release; the suspension was then sprayed on all leaves until runoff. Ten plants were sprayed with sterile water and served as control. Plants were covered with polythene bags and incubated in a growth chamber for $48 \mathrm{~h}$ at $18^{\circ} \mathrm{C}$. Plants were then maintained outdoors in a $50 \%$ shade-house at $85 \%$ to $100 \%$ relative humidity and between $16^{\circ}$ and $25^{\circ} \mathrm{C}$. The pathogenicity test was carried out twice. Characteristic symptoms and signs of downy mildew on inoculated plants appeared at 6 to 7 days after inoculation; by 10 days, disease symptoms were well-developed and were similar to those observed in the field, while control plants remained symptomless. Microscopic observation of leaf tissues of symptomatic plants confirmed the presence of the pathogen.

The disease shares some characteristic symptoms and signs on leaves with the previous report of downy mildew caused by Peronospora rumicis on $\mathrm{R}$. vesicarius $(1,2)$. Sporangiophore and sporangia dimensions of Peronospora rumicis and Pseudoperonospora rumicis overlap (2); however, the sporangia of the oomycete we observed germinated indirectly by producing globose zoospores. Furthermore, sporangiophores were longer, and were grouped in higher number in stomata compared to Peronospora. Based on these morphological characteristics and the criteria described by Spencer (3), the pathogen was identified as Pseudoperonospora rumicis. A voucher specimen has been deposited with the Herbarium Cryptogamae Indiae Orientalis (HCIO), Division of Plant Pathology, Indian Agricultural Research Institute (IARI), New Delhi (accession no. 48468). To our knowledge, this is the first report of Pseudoperonospora rumicis on R. vesicarius in India. Pseudoperonospora rumicis is the second downy mildew pathogen recorded on Rumex vesicarius and is of potential concern to Rumex growers.

\section{Literature Cited}

1. Sydow, H. 1914. Beitrage zur Kenntnis der Pilzflora des Sudlichen Ostindens. Ann. Mycol. 12:484-490.

2. Hall, G. 1994. No. 120 sheet 1199, IMI Description of Fungi and Bacteria. CABI Bioscience, Wallingford, Oxfordshire, UK.

3. Spencer, D. M. 1981. The Downy Mildews. Academic Press, New York, NY. 